\title{
Subduction and cumulate processes for the origin of eclogite xenoliths from Wajrakarur kimberlite field, Eastern Dharwar craton
}

\author{
JITEN PATTNAIK ${ }^{1}$, SUJOY GHOSH ${ }^{1}$ AND E.V.S.S.K. \\ $\mathrm{BABU}^{2}$ \\ ${ }^{1}$ Indian Institute of Technology Kharagpur \\ ${ }^{2}$ CSIR-National Geophysical Research Institute \\ Presenting Author: 28jiten@gmail.com
}

Petrology, mineral major, and trace element concentrations of eclogite xenoliths from Wajrakarur kimberlites on the Eastern Dharwar craton were investigated in order to constrain their origin and metasomatic processes which had led to their formation and eclogitisation in the Dharwar cratonic lithosphere. These mafic xenoliths have equilibrated at pressure and temperature conditions of 3.1- 4.7 GPa and 789.1- $1159.3{ }^{\circ} \mathrm{C}$ with a depth range of 103-152 km. Eclogitic garnets $\left(\mathrm{Py}_{26-}\right.$ ${ }_{50} \mathrm{Alm}_{18-35} \mathrm{Grs}_{21-46}$ ) except KL2-B1-2 (Grospydite garnet) display LREE depleted patterns along with positive $\mathrm{Eu}$ anomaly. Clinopyroxenes with Mg\# of 82-90 exhibit LREE enriched patterns and are treated as the counterparts of garnets in these mafic rocks. Reconstructed whole-rock trace element patterns typically show enrichment in $\mathrm{Eu}$ and $\mathrm{Sr}$ along with depletion in $\mathrm{Ti}$ (except KL2 B1) and Rb, varying with a broad range of $\mathrm{Nb}_{\mathrm{N}} / \mathrm{La}_{\mathrm{N}}$ (0.04-0.92) and high $\mathrm{Sr}_{\mathrm{N}} / \mathrm{Nd}_{\mathrm{N}}$ (2.44-7.75) values. Clinopyroxene-garnet trace element distribution coefficients for $\mathrm{Ce}, \mathrm{Y}, \mathrm{Sr}$, and $\mathrm{Gd}$ decrease with the increase in grossular components. These xenoliths have originated as low-pressure gabbroic cumulates and are formed by subduction of ancient oceanic crust. The gabbroic protoliths have undergone silicic partial melt loss chemically synchronous to modern oceanic gabbros, which rise and interact with the peridotitic mantle and later formed as tonalite-trondhjemite-granodiorite in the Dharwarian crust. These eclogites samples show $\mathrm{Ce} / \mathrm{Yb}_{\mathrm{NMORB}} \geq$ 1 and $\mathrm{La}_{\mathrm{N}} / \mathrm{Yb}_{\mathrm{N}}>1$ which have undergone melt metasomatism. Clinopyroxene is the primary carrier of metasomatism evidenced by the clinopyroxene-garnet trace element distribution coefficients. REE concentration of hypothetical melts in equilibrium with the eclogitic clinopyroxenes mirror ultramafic carbonated low volume melts similar to the kimberlites and orangeites of the Dharwar craton. Trace element modeling suggests eclogites of the Wajrakarur cluster have encountered progressive fractional melting compared to the higher degree of batch melting in the Kalyandurg cluster. Partial melting of the downgoing subducted oceanic crust leaves an eclogite residue which is transported to the upper mantle of the Dharwar craton via kimberlite eruption. We, therefore, suggest that these gabbroic eclogites formed by partial melting of the subducted oceanic crust, are chemically modified by ultramafic carbonated low volume melts upon being transported by Mesoproterozoic Wajrakarur kimberlites. 